\section{E A Institute of \\ YK Business Administration \\ 光下 \\ Karachi \\ Leadership and Ideas for Tomorrow}

Article 16

Volume 10 Issue 1 January - June 2015

$1-1-2015$

\title{
Back Matter of Volume 10 Number 1
}

Tufail A. Qureshi

Institute of Business Administration Karachi, Pakistan

Follow this and additional works at: https://ir.iba.edu.pk/businessreview

Part of the Business Commons

(c) (i)

This work is licensed under a Creative Commons Attribution 4.0 International License.

\section{Recommended Citation}

Qureshi, T. A. (2015). Back Matter of Volume 10 Number 1. Business Review, 10(1). Retrieved from https://doi.org/10.54784/1990-6587.1324 


\section{IBA \\ 徂炎 \\ BUSINESS REVIEW \\ Research Journal \\ of \\ The Institute of Business Administration \\ Karachi, Pakistan}

\section{Guidelines for Contributors}

Business Review is a biannual publication of the Institute of Business Administration, Karachi, Pakistan. It is a multidisciplinary journal covering a wide range of issues in the areas of business, social and management sciences, administration and governance, mathematics and computer studies, finance, economics, psychology, business ethics, logic, history of ideas, and philosophy of comparative religion.

\section{Guidelines for Authors}

1. Business Review invites the following types of contributions:

- Research papers

- Case studies and discussion papers

- Articles / Book Reviews

- Brief reports and comments

2. Manuscript should be submitted to the Editor, Business Review, Institute of Business Administration, University Road, Karachi, Pakistan.

3. Three copies of the manuscript should be submitted.

4. The text should be double spaced, on one side of the quarto paper allowing wide margins for referee's comments.

5. All illustrations, tables, etc., should be placed on separate sheets, included with each copy. Their placement should be indicated in the text.

6. Footnotes should be numbered consecutively through the text.

7. The first page of the manuscript should contain the following information. (i) title of the paper; (ii) the names(s) and institute affiliation(s) of the author(s); (iii) a footnote should give the name, postal address,telephone and fax number, and an email address of the authors.

8. The second page must contain the title, and abstract not exceeding 300 words, a maximum of 5 key words or phrases and appropriate JEL codes to be used for indexing purpose. The text will start on page number 3 .

9. Acknowledgements of all sorts should be included on the first page.

10. All mathematical derivations should be presented on a separate sheet, (not to be published) to help the referees.

11. Manuscript should include only those references that are cited in the text. Authors are advised to follow American Psychological Association (APA) style of referencing.

12. All literary material, including books, journals and manuscripts for review should be submitted in triplicate to the Editor, Business Review, Institute of Business Administration, University Road, Karachi, Pakistan.

13. It is assumed that the paper submitted is an original unpublished work and it has not already been published or submitted for publication elsewhere.

14. The opinions, ideas and evaluations expressed in the articles printed in the Business Review do not necessarily represent the views or policies of The Institute of Business Administration or the Editorial Board. They should be considered as representative example of opinions and analysis now current in the academic field on various subjects of intellectual, educational and cultural interest.

15. After internal evaluation, the Editor will send the selected articles to the external referees or the consulting foreign editors for their evaluation. Selection of the referees will be the discretion of the Editor.

16. The articles will be evaluated through anonymous peer reviews. Papers will normally be scrutinized and commented on by at least two independent expert referees in addition to the Editor.The referees will not be made aware of the identity of the author. All information about authorship will be removed from the papers.

17. The text of this publication or any part thereof may not be reproduced in any form or manner whatsoever without the permission in writing from the Editor.

For advance electronic submission of the material:

Main Campus: University Road, Karachi. Tel: (92-21) 38104700 Fax: (92-21) 99261508

City Campus: Garden/Kiyani Shaheed Road, Karachi.

Website: www.lba.edu.pk Email: tqureshi@iba.edu.pk

All enquiries should be addressed to the Editor, Business Review, Research Journal of The Institute of Business Administration, Karachi, Pakistan. 


\section{IBA 谈א \\ Institute of \\ Business Administration \\ Karachi-Pakistan}

\section{The Yogi and the Commissar}

The essence of the creative leader is that he is, in Koestler's phrase, both yogi and commissar. Perhaps the phrase need explaining, since the concepts it embodies are important to big organizations, which badly need both. Nobody, or virtually nobody, is pure yogi or pure commissar, but most people polarize around one or the other.

The yogi is the contemplative man, the thinker... The commissar, on the other hand, is the man of action. He has never had an idea in his life, and is incapable of questioning the assumption on which his department or the company is running...

Good commissars do not need to be chased or prodded: They have the drive inside them, they enjoy pushing things along, they find satisfaction and fulfillment in rushing around getting things done - and it is the actual doing, not the contemplation of the thing done, which is the source of their pleasure.

Good yogis and good commissars are not all that common. Obviously, therefore, the man who is a combination of both is rarer still. Nevertheless it is still vital to understand him, because although the spectacular conjunction of the brilliant original thinker with the vigorous and decisive man of action may not crop up more than once in a generation. And these are the people who can lead the creative groups, by virtue of the dual insight which the combination of these qualities gives them. In his creative group there will be some who are more yogi than commissar, some who are more commissar than yogi; clearly it is excellent if he is better than all of them in both areas, but it is not essential. So long as he is good enough to be respected by the yogis as a yogi and by the commissars as a commissar, so long as he is much more of a yogi than any of the commissars and much more of a commissar than any of the yogis, that is what matters, because he will have the one thing that none of the rest possess, namely, an understanding of the whole operation, and not merely sections or aspects of it.

Antony Jay, Management and Machiavelli, pp.115-118 